\title{
Efek Pengurangan Durasi Tidur terhadap Jumlah dan Hitung Jenis Leukosit pada Tikus Wistar
}

\author{
Wahyu Tri Novriansyah ${ }^{1}$, Ellyza Nasrul ${ }^{2}$, Rosfita Rasyid ${ }^{3}$
}

\begin{abstract}
Abstrak
Sleep Deprivation (SD) adalah hilangnya waktu tidur komplit untuk periode tertentu ataupun durasi tidur yang lebih pendek dari waktu optimal yang dibutuhkan. Sleep deprivation mempengaruhi sistem kekebalan tubuh sebagaimana terganggunya irama sirkadian. Tujuan peneltian ini adalah menentukan efek dari sleep deprivation terhadap jumlah dan hitung jenis leukosit pada tikus wistar. Penelitian ini adalah studi eksperimental terhadap 24 ekor tikus yang dibagi menjadi empat kelompok, terdiri dari kelompok kontrol (K0), kelompok perlakuan P1 (SD 48 jam), P2 (SD 72 jam) dan P3 (SD 96 jam). Jumlah leukosit, eosinofil, neutrofil, limfosit dan monosit diperiksa dengan Blood Analyzer Impedant Pentra 60. Analisis data menggunakan one way Anova dengan signifikansi $\mathrm{p}<0,05$. Hasil yang didapat ialah jumlah leukosit pada kelompok perlakuan P1, P2 dan P3 tidak menunjukkan perbedaan signifikan $(12091 \pm 4712,3)$. Hitung eosinofil menunjukkan adanya peningkatan signifikan pada kelompok P1 $(0,93 \pm 0,7)$ dan P2 $(1,75 \pm 1,5)$ dibandingkan $K 0(0,13 \pm 0,08)$. Pada $P 3(0,32 \pm 0,35)$ terlihat penurunan hitung eosinofil yang signifikan dibandingkan dengan kelompok P2. Hitung neutrofil menurun pada kelompok $\mathrm{P} 3$ $(6,5 \pm 8,1)$ dibandingkan dengan kelompok K0 $(10,9 \pm 3,7)$ dan P2 $(13,5 \pm 4,2)$. Hitung limfosit menurun pada P2 $(78,1 \pm 7,3)$ dibanding $\mathrm{K} 0(86,3 \pm 3,9)$, dan meningkat pada P3 $(87,4 \pm 6,5)$ dibanding P2. Monosit pada kelompok perlakuan P1, P2 dan P3 tidak menunjukkan perbedaan signifikan $(2,0 \pm 0,5)$.
\end{abstract}

Kata kunci: sleep deprivation, leukosit, eosinofil, neutrofil, limfosit, monosit

\section{Abstract}

Sleep Deprivation (SD) is a complete loss of sleep for a certain period or a shorter sleep duration than the optimal time required. Sleep deprivation affects the immune system as well as the disruption of circadian rhythms. The objective of this study was to determine the effect of sleep deprivation on total and differential counting of leukocytes. This was an experimental study on 24 rats which divided into four groups, consisting of the control group (KO), the treatment group P1 (SD 48 hours), P2 (SD 72 hours), and P3 (SD 96 hours). After treatment, total number leukocytes, eosinophils, neutrophils, lymphocytes and monocytes were calculated using a blood analyzer impedant pentra 60. Analysis of the data using a one way ANOVA with significance $p<0.05$. The number of leukocytes in the treated group P1, P2 and P3 showed no significant difference (12091 \pm 4712.3$)$. Eosinophil count results showed a significant increase in the $P 1$ group $(0.93 \pm 0.7)$ and $P 2(1.75 \pm 1.5)$ compared to KO (0.13 $\pm 0.08)$. The $P 3(0.32 \pm 0.35)$ showed a significant reduction in eosinophil count compared with the $P 2$ group. Neutrophil count decreased in the $P 3$ group (6.5 \pm 8.1) compared with the group K0 (10.9 \pm 3.7$)$ and P2 (13.5 \pm 4.2). Lymphocyte count decreased in $P 2$ (78.1 \pm 7.3$)$ compared to $K 0$ (86.3 \pm 3.9$)$, and increases in $P 3$ (87.4 \pm 6.5) compared to $P 2$. Monocytes in $P 1, P 2$ and $P 3$ showed no significant difference $(2.0 \pm 0.5)$.

Keywords: sleep deprivation, leukocytes, eosinophil, neutrophil, limfosit, monocyte

Affiliasi Penulis: 1. Prodi Profesi Dokter FK UNAND (Fakultas Kedokteran Universitas Andalas Padang), 2. Bagian Patologi Klinik FK UNAND, 3. Bagian IImu Kesehatan Masyarakat FK UNAND
Nama Penulis: Wahyu Tri Novriansyah, Email: wahyukurangkerjaan@gmail.com, Telp: 081275966119 


\section{PENDAHULUAN}

Sleep Deprivation (SD) didefinisikan sebagai hilangnya waktu tidur komplit untuk periode tertentu ataupun durasi tidur yang lebih pendek dari waktu tidur optimal yang dibutuhkan. Hal tersebut dapat menimbulkan gangguan siklus tidur dan menimbulkan konsekuensi lainnya sebagaimana terganggunya irama sirkadian. ${ }^{1}$ Konsekuensi sleep deprivation terhadap sistem kekebalan tubuh mengungkapkan adanya perubahan kualitas dan kuantitas dari komponen penyusun sistem imun tubuh. Hal tersebut dapat membawa pada resiko penyakit infeksi ataupun kronis yang lebih tinggi. ${ }^{2}$

Studi mengenai hubungan antara tidur, irama sirkadian dan melatonin dengan imunitas menunjukkan keterkaitan yang erat. Tidur dan irama sirkadian adalah regulator yang kuat terhadap proses imunologi. Fisiologi dasar dari pengaruh tersebut adalah komunikasi dua arah antara sistem saraf pusat dan sistem imun yang dimediasi oleh sinyal-sinyal neurotransmiter, hormon dan sitokin, serta inervasi langsung terhadap sistem imun oleh sistem saraf otonom. Beberapa fungsi imun terlihat menonjol sesuai irama yang secara sinkron siklus 24 jam regular, merefkleksikan adanya aksi sinergik tidur dan irama sirkadian dengan proses imunologi. ${ }^{3}$

Jumlah sel T helper dan sel Natural Killer mengalami penurunan setelah satu malam sleep deprivation, namun aktivitas sel Natural Killer justru meningkat setelah dua malam sleep deprivation. Bahkan, sleep deprivation selama 64 jam justru meningkatkan jumlah hitung neutrofil dan monosit. Bagaimana mekanisme sleep deprivation dapat mempengaruhi sistem imun belumlah jelas. ${ }^{4}$ Efisiensi tidur yang jelek dan durasi tidur yang singkat selama seminggu dapat meningkatkan kerentanan terhadap infeksi rhinovirus dan

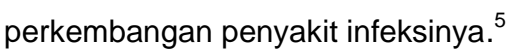

Tidur dapat meningkatkan respon imun adaptif yang dibuktikan dengan peningkatan signifikan dari jumlah sel pre $\mathrm{mDC}$ yang memproduksi IL-12 sebagai penginduksi utama respon sel Th1 ${ }^{6}$ Studi yang menggunakan leukosit sebagai parameter sistem imun belum membuktikan apakah perubahan jumlah leukosit dalam darah yang ditemukan setelah sleep deprivation mengikuti proses fungsional pada tingkat selular ataupun

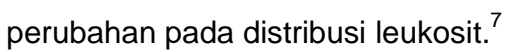

Penelitian ini bertujuan untuk mengetahui efek dari sleep deprivation terhadap jumlah dan hitung jenis leukosit pada tikus wistar.

\section{METODE}

Jenis penelitian ini adalah true experimental research dengan rancangan Randomized post Control Group. Sampel penelitian adalah 28 ekor tikus wistar berumur tiga bulan dengan berat 150 250 gram. Proses adaptasi dilakukan selama 1 minggu dengan pemberian pakan standar di Laboratorium Farmasi Universitas Andalas. Ke-28 ekor tikus kemudian dibagi ke dalam empat kelompok yang dipilih secara random. Kelompok Kontrol (K0) hanya akan diberikan pakan standar saja. Kelompok perlakuan 1 (P1) akan dikondisikan sleep deprivation selama 48 jam. Hal serupa juga dilakukan pada Kelompok Perlakuan 2 (P2) dengan SD selama 72 jam dan Kelompok Perlakuan 3 (P3) dengan SD selama 96 jam. Pemberian makanan diberikan secara ad libitum.

Modified multiple platform method digunakan untuk membatasi tidur fase REM sehingga tikus akan mengalami paradoxycal sleep deprivation. Tikus akan diletakkan di atas platform (panggung kecil) seluas $4 \times 4 \times 3 \mathrm{~cm}$ di dalam sebuah wadah $p$ $x$ I $x \mathrm{t}, 65 \mathrm{~cm} \times 45 \mathrm{~cm} \times 40 \mathrm{~cm}$ dan diisi air setinggi 2 $\mathrm{cm}$. Wadah diisi 8 platform untuk 7 ekor tikus.

Pada akhir durasi sleep deprivation, darah tikus akan diambil dari ekor sebanyak 0,25cc-0,5 cc. Sampel darah kemudian dibawa ke Laboratorium Sentral FK Unand untuk dibuat preparat darahnya dan dihitung jumlah serta hitung jenis leukositnya dengan menggunakan mikroskop dan Automatic Blood Hematology Auto Analyzer Blood Test Machine. 


\section{HASIL DAN PEMBAHASAN}

Penelitian ini dibagi menjadi empat kelompok yaitu, kelompok kontrol (K0), perlakuan SD selama 48 jam (P1), perlakuan SD selama 72 jam (P2), perlakuan SD selama 96 jam (P3). Perlakuan dimulai pada pukul 09.00 malam dan diakhiri pada jam yang sama sesuai dengan kelompok perlakuan masing-masing. Sesaat setelah diperlakukan sesuai kelompok, diambil sampel darah hewan coba untuk kemudian dihitung jumlah dan hitung jenis leukositnya.

\section{Efek Pengurangan Durasi Tidur terhadap}

\section{Jumlah Leukosit}

Rerata jumlah leukosit setelah perlakuan sleep deprivation disajikan dalam tabel berikut ini.

Tabel 1. Efek pengurangan durasi tidur terhadap jumlah leukosit

\begin{tabular}{cccc}
\hline Group & $\begin{array}{c}\text { Durasi } \\
\text { Sleep } \\
\text { Deprivation }\end{array}$ & $\begin{array}{c}\text { Jumlah Total } \\
\text { Leukosit } / \mathbf{m m}^{3}\end{array}$ & $\mathbf{p}$ \\
Rerata \pm sd & \\
\hline K0 & 0 jam & $12091 \pm 4712,3$ & \\
P1 & 48 jam & $11883,3 \pm 4348,0$ & 0,653 \\
P2 & 72 jam & $8850,0 \pm 2121,0$ & \\
P3 & 96 jam & $11800 \pm 7616,8$ &
\end{tabular}

Uji one-way ANOVA. Data menunjukkan perbedaan yang bermakna apabila $p \leq 0,05$

Tabel 1 menggambarkan uji one-way ANOVA, didapatkan nilai $p=0,653$. Karena $p>0,05$, dapat ditarik kesimpulan bahwa tidak terdapat perbedaan yang bermakna pada jumlah total leukosit pada seluruh kelompok.

Pada penelitian ini tidak didapatkan adanya perbedaan yang bermakna pada jumlah total leukosit setelah perlakuan pengurangan durasi tidur (Sleep deprivation/SD) selama 48 jam, 72 jam, dan 96 jam $(p=0,355)$. Hal ini berbeda dengan hasil penelitian Zager et al, yang menemukan terjadinya peningkatan jumlah leukosit pada hewan coba setelah perlakuan SD 96 jam jika dibandingkan dengan kelompok perlakuan SD 24 jam. ${ }^{8}$ Pada penelitian lain yang dilakukan Everson, jumlah total leukosit dan limfosit secara signifikan meningkat setelah perlakuan sleep deprivation selama 12-22 hari.] namun tidak menunjukkan perbedaan yang

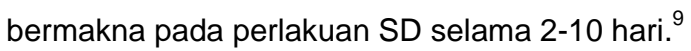

Leukositosis yang diinduksi melalui sleep deprivation telah diteliti sejak tahun. Tidak ditemukan adanya perubahan jumah leukosit manusia setelah mengalami sleep deprivation selama 48 jam. $^{10}$ Perbedaan hasil penelitian ini dengan penelitian sebelumnya mungkin disebabkan karena perbedaan durasi SD seperti yang dilaporkan pada penelitian yang dilakukan.,

\section{Efek Pengurangan Durasi Tidur terhadap Hitung Eosinofil}

Hasil uji normalitas data Saphiro-Wilk test, didapatkan distribusi data untuk hitung eosinofil tak normal, maka dilakukan transformasi data menggunakan Log10.

Tabel 2. Efek pengurangan durasi tidur terhadap hitung eosinofil

\begin{tabular}{cccc}
\hline Group & $\begin{array}{c}\text { Durasi } \\
\text { Sleep } \\
\text { Deprivation }\end{array}$ & $\begin{array}{c}\text { Jumlah Eosinofil } \\
(\%)\end{array}$ & $\begin{array}{c}\mathbf{p} \\
\text { (log10 }\end{array}$ \\
\hline K0 & 0 jam & $0,13 \pm 0,08$ & \\
P1 & 48 jam & $0,93 \pm 0,7$ & \\
P2 & 72 jam & $1,75 \pm 1,5$ & 0,001 \\
P3 & 96 jam & $0,32 \pm 0,35$ &
\end{tabular}

Uji one-way ANOVA. Data menunjukkan perbedaan yang

bermakna apabila $p \leq 0,05$

Setelah dilakukan uji one way ANOVA, maka untuk melihat signifikansi hasil hitung eosinofil pada setiap kelompok dilakukan uji post hoc LSD.

Tabel 3. Perbedaan hitung eosinofil pada masingmasing kelompok

\begin{tabular}{ccc}
\hline $\mathbf{n = 7}$ & Kelompok & $\mathbf{p}$ \\
\hline Perlakuan & Log K0 vs Log P1* & 0,004 \\
& Log K0 vs Log P2* & 0,0001 \\
& Log K0 vs Log P3 & 0,219 \\
& Log P1 vs Log P2 & 0,243 \\
& Log P1 vs Log P3 & 0,058 \\
& Log P2 vs Log P3* & 0,005
\end{tabular}

Uji Post-Hoc LSD. Data menunjukkan perbedaan apabila $(p \leq 0,05){ }^{*}$ Terdapat perbedaan signifikan 
Berdasarkan hasil uji One Way ANOVA, terdapat perbedaan yang bermakna $(p<0,05)$ pada seluruh kelompok perlakuan sleep deprivation terhadap (Log10) hasil hitung eosinofil (Tabel 3). Pada uji post hoc LSD, terdapat perbedaan yang bermakna $(p<0,05)$ pada kelompok hasil transformasi data (Log10) eosinofil P1 (48 jam) terhadap kelompok K0; P2 (72 jam) terhadap kelompok K0; dan kelompok P3 (96 jam) terhadap P2 (72 jam). Berdasarkan hasil tersebut, terdapat perbedaan hitung eosinofil (Log10) yang bermakna pada kelompok perlakuan P1 dan P2 (48 dan 72 jam) terhadap kelompok kontrol. Hasil hitung eosinofil (Log10) tidak menunjukkan adanya perbedaan yang bermakna pada kelompok P3 (96 jam) terhadap K0; kelompok P3 (96 jam) terhadap P1 (48 jam) ;dan P2 (72 jam)terhadap P1 (48 jam). Hasil hitung eosinofil (Log10) meningkat pada kelompok perlakuan P1 (48 jam) dan P2 (72 jam), namun kemudian menurun pada kelompok perlakuan P3 (96 jam).

Perbedaan bermakna terlihat pada hasil hitung eosinofil $(p<0,05)$. Hasil uji selanjutnya menunjukan adanya peningkatan hitung eosinofil pada hewan coba setelah perlakuan sleep deprivation 48 jam dan 72 jam. Pada kelompok perlakuan sleep deprivation 96 jam terlihat penurunan hitung eosinofil yang signifikan jika dibandingkan dengan kelompok perlakuan sleep deprivation 48 jam dan 72 jam. Penelitian eksperimental sebelumnya belum pernah menemukan bahwa terjadinya perubahan bermakna pada hitung eosinofil dengan sleep deprivation sebagai variabel tunggal.

Hitung eosinofil menunjukkan penurunan sebanyak $30 \%$ dari kelompok kontrol pada partisipan laki-laki muda yang mengikuti pelatihan militer selama 5-7 hari dan menjalani latihan fisik yang kontinyu, defisiensi kalori dan sleep deprivation. Penelitian tersebut menggabungkan sleep deprivation, defisiensi kalori dan latihan fisik yang kontinyu sebagai variabelnya. ${ }^{11}$ Jumlah granulosit meningkat setelah 24 jam perlakuan sleep deprivation, namun tidak dipaparkan lebih lanjut berapa presentase eosinofil dari jumlah granulosit tesebut. $^{12}$

Sleep deprivation dapat dikatakan sebagai stres berat yang dapat mengakibatkan perubahan buruk pada kesehatan dan fungsi imunitas. ${ }^{13}$ Sleep deprivation dapat dikatakan sebagai stres berat yang dapat mengakibatkan perubahan buruk pada kesehatan dan fungsi imunitas. Eosinofilia yang terjadi pada penelitian ini setelah perlakuan sleep deprivation selama 48 dan 72 jam, kemungkinan menggambarkan adanya alergi berat atau peningkatan status imunitas dari tikus setelah mengalami stres berat. Stres berat mengaktifkan jalur Hypothalamic-pituitary-adrenal (HPA), Sympatethic Adrenal Medullary (SAM) dan sympatethic Nervus System (SNS). Aktivasi tersebut menyebabkan pelepasan epinefrin dan norepinefrin dan berikatan dengan reseptornya, reseptor adrenergik pada sel T (Th2) dan B. Terbentuk respon humoral meliputi pelepasan interleukin (IL)-4, IL-5 dan IL-13 mengikuti paparan alergen dan pelepasan histamin oleh aktivasi sel mast dan basofil. Selanjutnya, diikuti aktivasi dan proliferasi eosinofil. ${ }^{14}$ Eosinofilia yang terjadi pada penelitian ini setelah perlakuan sleep deprivation dalam waktu 48 dan 72 jam, kemungkinan menggambarkan adanya alergi berat atau peningkatan status imunitas dari tikus setelah mengalami stres berat. ${ }^{14,15}$

Penurunan hitung eosinofil setelah perlakuan sleep deprivation selama 96 jam jika dibandingkan dengan sleep deprivation 48 jam dan 72 jam kemungkinan menunjukkan adanya penurunan status imunitas tubuh setelah sebelumnya diberikan stres berat dan tubuh tak lagi mampu beradaptasi untuk menghadapi stres berkelanjutan tersebut. Walaupun pada penelitian ini, penurunan tersebut tidak bermakna dibandingkan dengan kelompok kontrol, sleep deprivation selama 96 jam dapat menyebabkan penurunan status imunitas yang bila dilanjutkan ke sleep deprivation yang lebih lama menyebabkan gagal melawan invasi patogen.,16 


\section{Efek Pengurangan Durasi Tidur terhadap Hitung Neutrofil}

Rerata hasil hitung neutrofil setelah perlakuan sleep deprivation disajikan dalam tabel.

Tabel 4. Efek pengurangan durasi tidur terhadap hitung neutrofil

\begin{tabular}{lccc}
\hline Group & $\begin{array}{c}\text { Durasi } \\
\text { Sleep } \\
\text { Deprivation }\end{array}$ & $\begin{array}{c}\text { Jumlah Neutrofil (\%) } \\
\text { Rerata } \pm \text { Standar } \\
\text { Deviasi }\end{array}$ & $\begin{array}{c}\mathbf{p} \\
\text { (log10 } \\
\text { netrofil) }\end{array}$ \\
\hline K0 & 0 jam & $10,9 \pm 3,7$ & \\
P1 & 48 jam & $9,6 \pm 8,7$ & 0,026 \\
P2 & 72 jam & $13,5 \pm 4,2$ & \\
P3 & 96 jam & $6,5 \pm 8,1$ &
\end{tabular}

Uji One Way ANOVA. Data menunjukkan perbedaan yang

bermakna apabila $p \leq 0,05$

Pada data hitung neutrofil dilakukan transformasi data (Log10) karena sebarannya tidak normal. Pada uji one way ANOVA didapatkan $p=0,026 \quad(p<0,05)$, sehingga dapat ditarik kesimpulan bahwa terdapat perbedaan yang bermakna pada hasil hitung neutrofil (Log10) pada seluruh kelompok perlakuan sleep deprivation. Untuk mengetahui signifikansi lebih lanjut, maka dilakukan uji post hoc LSD.

Tabel 5. Perbedaan hitung neutrofil pada masingmasing kelompok

\begin{tabular}{ccc}
\hline & Kelompok & p \\
\hline Perlakuan & Log K0 vs Log P1 & 0,418 \\
& Log K0 vs Log P2 & 0,562 \\
& Log K0 vs Log P3* & 0,018 \\
& Log P1 vs Log P2 & 0,172 \\
& Log P1 vs Log P3 & 0,095 \\
& Log P2 vs Log P3 & 0,005
\end{tabular}

Uji Post-Hoc LSD. Data menunjukkan perbedaan apabila $(\mathrm{p} \leq$ $0,05) .{ }^{*}$ Terdapat perbedaan signifikan

Hasil uji post hoc LSD, didapatkan pada kelompok P3 (96 jam) terhadap $\mathrm{K} 0$, nilai $\mathrm{p}=0,018$ $(p<0,05)$, sehingga dapat disimpulkan bahwa adanya perbedaan yang bermakna dari hasil hitung jumlah neutrofil (Log10) pada kelompok P3 (96 jam) terhadap K0. Selain itu, didapatkan pada kelompok P2 (72 jam) terhadap P3 (96 jam), nilai $\mathrm{p}=0,005$ $(p<0,05)$, sehingga dapat disimpulkan bahwa adanya perbedaan yang bermakna dari hasil hitung neutrofil (Log10) pada kelompok P2 (72 jam) terhadap P3 (96 jam).

Penelitian ini menemukan adanya penurunan hitung neutrofil pada hewan coba setelah perlakuan sleep deprivation selama 96 jam jika dibandingkan dengan kelompok perlakuan sleep deprivation 72 jam dan kelompok kontrol. Sejalan dengan penelitian ini, Irwin melaporkan adanya penurunan hitung neutrofil pada hari ketiga perlakuan Partial Sleep deprivation. ${ }^{17}$ Penelitian lain mengungkapkan pada hitung jenis neutrofil, terjadi peningkatan yang bermakna dari kelompok kontrol pada tikus perlakuan sleep deprivation selama 2-10 hari dan 12-20 hari. $^{9}$ Penelitian yang dilakukan Zager et al menemukan adanya penurunan hitung neutrofil pada hewan coba yang dikondisikan mengalami pembatasan jumlah tidur selama 21 hari dengan waktu tidur 6 jam perharinya, dibandingkan dengan kelompok hewan coba yang mengalami sleep deprivation selama 96 jam. $^{8}$

\section{Efek Pengurangan Durasi Tidur terhadap Hitung Limfosit}

Rerata hasil hitung limfosit setelah perlakuan sleep deprivation disajikan dalam tabel berikut ini.

Tabel 6. Efek pengurangan durasi tidur terhadap hitung limfosit

\begin{tabular}{cccc}
\hline Group & $\begin{array}{c}\text { Durasi } \\
\text { Sleep } \\
\text { Deprivation }\end{array}$ & $\begin{array}{c}\text { Jumlah Limfosit } \\
(\%) \\
\text { Rerata } \pm \text { Standar } \\
\text { Deviasi }\end{array}$ & p \\
\hline K0 & 0 jam & $86,3 \pm 3,9$ \\
P1 & 48 jam & $83,2 \pm 10,1$ & \\
P2 & 72 jam & $78,1 \pm 7,3$ & 0,045 \\
P3 & 96 jam & $87,4 \pm 6,5$ & \\
\hline Uji Kruskal-Wallis. Data menunjukkan perbedaan yang bermakna \\
apabila $p \leq 0,05$
\end{tabular}


Pada analisis data dengan uji Kruskal-Wallis diperoleh nilai $\mathrm{p}=0,045(>0,05)$, sehingga diambil kesimpulan terdapat perbedaan yang bermakna dari semua kelompok perlakuan sleep deprivation terhadap hasil hitung limfosit.

Tabel 7. Perbedaan hitung limfosit pada masingmasing kelompok

\begin{tabular}{ccc}
\hline & Kelompok & p \\
\hline Perlakuan & Log K0 vs Log P1 & 0,747 \\
& Log K0 vs Log P2 & 0,037 \\
& Log K0 vs Log P3 & 0,261 \\
& Log P1 vs Log P2 & 0,078 \\
& Log P1 vs Log P3 & 0,150 \\
& Log P2 vs Log P3 & 0,025
\end{tabular}

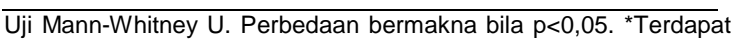
perbedaan yang bermakna

Pada uji Mann-U-Whitney, didapatkan nilai $\mathrm{p}=$ 0,037 pada kelompok P2 (72 jam) terhadap K0 $(p<0,05)$, sehingga ditarik kesimpulan, terdapat perbedaan bermakna pada limfosit tikus kelompok P2 (72 jam) terhadap K0. Selain itu, hasil hitung limfosit pada kelompok P3 (96 jam) terhadap P2 (72 jam) juga menunjukkan adanya perbedaan yang bermakna dengan nilai $p=0,025(p<0,05)$.

Penelitian ini menemukan adanya penurunan hitung limfosit setelah sleep deprivation selama 72 jam. Namun, setelah perlakuan sleep deprivation selama 96 jam terjadi peningkatan hitung limfosit jika dibandiingkan dengan sleep deprivation selama 72 jam. Pada penelitian Ruiz et al dilaporkan bahwa terjadi penurunan hitung limfosit yang signifikan pada tikus yang mengalami diabetes non-obesitas (non-obese diabetic) dengan perlakuan sleep deprivation selama 96 jam dan 24 jam terhadap kelompok kontrol. ${ }^{2}$ Zager et al mengungkapkan sleep deprivation selama 24 jam secara signifikan menurunkan jumlah limfosit dibandingkan dengan kelompok kontrol. sleep deprivation selama 96 jam memberikan hasil hitung limfosit yang lebih tinggi daripada kelompok hewan sleep deprivation24 jam. ${ }^{8}$

Peneliti lain melaporkan adanya penurunan jumlah sel $\mathrm{T}$ Helper dan kemampuan sitotoksisitas Natural Killer setelah perlakuan sleep deprivation selama 64 jam pada manusia. ${ }^{17}$ Sleep deprivation selama 48 jam menurunkan jumlah sel NK sebanyak $30 \%{ }^{10}$ Hasil penelitian ini yang tidak sejalan dengan penelitian sebelumnya, mungkin disebabkan oleh beberapa faktor yang berbeda. Pada penelitian Ruiz et al, tikus yang digunakan adalah tikus diabetes non-obesitas. ${ }^{2}$ Pada penelitian Zager et al, perbandingan hasil limfosit ditunjukkan pada kelompok hewan coba sleep deprivation 96 jam terhadap sleep deprivation 24 jam. ${ }^{8}$ Pada penelitian ini durasi sleep deprivation selama 24 jam tidak diteliti.

\section{Efek Pengurangan Durasi Tidur terhadap Hitung Monosit}

Rerata hasil hitung monosit setelah perlakuan sleep deprivation disajikan dalam tabel berikut ini. Hasil uji normalitas data Saphiro-Wilk test, didapatkan data untuk hitung monosit tak normal, maka dilakukan transformasi data (Log10).

Tabel 8. Efek pengurangan durasi tidur terhadap hitung monosit

\begin{tabular}{cccc}
\hline & Jumlah Monosit & \\
Group & $\begin{array}{c}\text { Sleep } \\
\text { Deprivation }\end{array}$ & $\begin{array}{c}\text { Rerata } \\
\pm \text { Standar } \\
\text { Deviasi }\end{array}$ & $\begin{array}{c}\mathbf{p} \\
\text { (Log10 } \\
\text { monosit) }\end{array}$ \\
& & $2,0 \pm 0,5$ & \\
K0 & 0 jam & $3,1 \pm 2,2$ & 0,719 \\
P1 & 48 jam & $2,8 \pm 1,4$ & \\
P2 & 72 jam & $4,8 \pm 3,6$ & \\
P3 & 96 jam & & \\
Uji one-way ANOVA. Data menunjukkan perbedaan bermakna \\
apabila $p \leq 0,05$
\end{tabular}

Uji one-way ANOVA (Tabel 8), didapatkan nilai $p=0,719$. Karena $p>0,05$, dapat ditarik kesimpulan bahwa tidak terdapat perbedaan yang bermakna pada hasil hitung monosit (Log10) pada seluruh kelompok perlakuan sleep deprivation.

Penelitian ini tidak menunjukkan adanya perbedaan bermakna dari hitung monosit setelah diperlakukan sleep deprivation selama 48 jam, 72 jam dan 96 jam. Hal ini juga sudah dibuktikan dalam penelitian Zager et al, yang tidak mendapatkan 
adanya perbedaan bermakna pada hitung monosit setelah perlakuan sleep deprivation selama 24 jam dan 96 jam. $^{8}$ Namun, penelitian lain mengungkapkan adanya peningkatan jumlah monosit pada hewan coba setelah dikondisikan sleep deprivation selama 12-22 hari. $^{9}$

Untuk melihat efek sleep deprivation terhadap parameter imun, sangat tergantung dengan waktu penilaian (pengambilan sampel darah). Pengambilan sampel darah yang hanya dilakukan satu kali, biasanya tidak menunjukkan data yang konklusif.

Berdasarkan penelitian terdahulu, siklus tidur per 24 jam memiliki aksi sinergik antara tidur, pelepasan hormon dan proses imunologi. Sleep deprivation menggangu ritme siklus tersebut sehingga fisiologis imunitas pun terganggu. ${ }^{3}$

Penggunaaan metode Modified Multiple Platform telah digunakan secara konsisten untuk menginduksi sleep deprivation pada hewan coba. Metode sebelumnya, yang menggunakan disk-overwater methode, menunjukkan adanya variabel lain selain sleep deprivation, yakni adanya tingkat stress akibat aktivitas fisik hewan coba. ${ }^{9}$ Perubahan jumlah ataupun hitung jenis leukosit di dalam darah dipengaruhi oleh berbagai macam faktor. Sleep deprivation sebagai salah satu faktornya telah diungkapkan memiliki hubungan terhadap pengaturan hormon kelenjar adrenal seperti kortikosteron sehingga mempengaruhi jumlah leukosit di sirkulasi. Adanya peningkatan berat limpa setelah pemberian perlakuan sleep deprivation mengindikasikan bahwa sleep deprivation berpengaruh terhadap sirkulasi dan proliferasi limfosit di limpa. ${ }^{8}$

Sleep deprivation dapat mengaktivasi produksi agen proinflamasi yang persisten, yang digambarkan sebagai inflamasi derajat rendah. Biila hal tersebut berlangsung lama dan berkelanjutan justru akan menyebabkan imunodefisiensi dan kegagalan imunitas tubuh. ${ }^{3}$

\section{KESIMPULAN}

Sleep deprivation selama 48 jam, 72 jam, 96 jam tidak memiliki efek terhadap jumlah total leukosit darah tepi pada tikus wistar.

Sleep deprivation selama 48 jam memiliki efek meningkatkan hasil hitung eosinofil darah tepi pada tikus wistar dibandingkan dengan kelompok kontrol. Sleep deprivation selama 72 jam memiliki efek meningkatkan hasil hitung eosinofil darah tepi pada tikus wistar dibandingkan dengan kelompok kontrol. Sleep deprivation selama 96 jam memiliki efek menurunkan hasil hitung eosinofil darah tepi pada tikus wistar dibandingkan dengan kelompok kelompok perlakuan sleep deprivation selama 72 jam.

Sleep deprivation selama 48 jam tidak memiliki efek terhadap hasil hitung neutrofil darah tepi pada tikus wistar. Sleep deprivation selama 72 jam tidak memiliki efek terhadap hasil hitung neutrofil darah tepi pada tikus wistar. Sleep deprivation selama 96 jam memiliki efek menurunkan hasil hitung neutrofilpada tikus wistar dibandingkan dengan kelompok kontrol dan kelompok perlakuan sleep deprivation selama 72 jam.

Sleep deprivation selama 48 jam tidak memiliki efek terhadap hasil hitung limfosit darah tepi pada tikus wistar. Sleep deprivation selama 72 jam memiliki efek menurunkan hasil hitung limfosit darah tepi pada tikus wistar dibandingkan dengan kelompok kontrol. Sleep deprivation selama 96 jam memiliki efek meningkatkan hasil hitung limfosit darah tepi pada tikus wistar dibanding group perlakuan selama 72 jam. 


\section{DAFTAR PUSTAKA}

1. Orzel J, Gryglewska. Consequences of sleep deprivation. Review Papers: University of Gdansk Poland; 2009.hlm.1-4.

2. Ruiz FS, Andersen ML, Zager A, Martins RCS, Tufik, S. Sleep deprivation reduces the lymphocyte count in a nonobese mouse model of type 1 diabetes melitus. Brazilian Journal of Medical and Biological Research. 2007; 40: 633-7.

3. Besedovsky L, Lange T, Born Jan. Sleep and immune function. Pflugers Arch- Eur J physiol. 2012; 463:121-37.

4. Dinges DF, Douglas SD, Zaugg L, Campbell DE, McMann JE, Whitehouse WG, et al. Leukocytosis and natural killer cell function parallel neurobehavioral fatigue induced by 64 hours of sleep deprivation. Pensylvania: University of Philadelphia; 1994.

5. Cohen S, Doyle WJ, Alper CM, Janicki-Deverts D, Turner RB. Sleep habit and susceptibility to the common cold. Arch Intern Med. 2009.169(1); 62-7.

6. Dimitrov S, Lange $\mathrm{T}$, Nohroudi $\mathrm{K}$, Born J. Number and function of circulating human antigen presenting cells regulated by sleep. Sleep. 2007;30(4) Tersedia dari: URL: HYPERLINK www.journalsleep.org/articles/ 300405.pdf

7. Bollinger $\mathrm{T}$, Bollinger $\mathrm{A}$, Oster $\mathrm{H}$, Solbach $\mathrm{W}$. Sleep, immunity, circadian clock: a mechanistic model. Gerontology. 2009;56:2009; 574.

8. Zager A, Andersen ML, Ruiz FS, Antunes IB, Tufik S. Effects of acute and chronic sleep loss on immune modulation of rats. Am J Physiol Regul Integr Comp Physiol. 2007;293:504-9.
9. Everson CA. Clinical assessment of blood leukocytes, serum cytokines, and serum immunoglobulins as responses to sleep deprivation in laboratory rats. Am J Phsiol Regul Integr Comp Physiol. 2005;289.

10. O"ztu"rk L, Pelin Z, Karadeniz D, Kaynak H, Csakar L, Go"zu"kirmizi E. Effects of 48 hours sleep deprivation on human immune profile. Sleep Res Online. 1999; 2:1999:107-11.

11. Boyum A, Wilk P, Gustavvson E, Veiby OP, Reseland J, Haugen AH, Opstad PK. The effect of strenuous exercise, calorie deficiency and sleep deprivation on white blood cells, plasma immunoglobulins and cytokines. Scandinavian Journal of Immunology. 2003;43(2): 228-35.

12. Heiser P, Dickhaus B, Schreiber W, Clement $\mathrm{HW}$, Hasse C, Hennig J, Remschmidt $\mathrm{H}$, et al. White blood cells and cortisol after sleep deprivation and recovery sleep in humans. Eur Arch Psychiatry Clin Neurosci. 2000;250: 16-23.

13. Bonnet Mh, Arand DL. We are chronically sleep deprived. Sleep.1995;18: 908-11.

14. Schwartz M, Kipnis J. A conceptual revolution in the relationship between the brain and immunity. Brain Behav Immun. 2011;25(8): 817-9.

15. Setyawan S. Eosinophilia in physical eercise stressor. pathobiology or physiobiology? Foila Medica Indonesia. 2005; 41(4).

16. Everson CA. Sustained Sleep deprivation impairs host defence. Am J Physiol. 1993; 265:R1148-R54.

17. Irwin M, Mascovich A, Gillin JC, Willoughby R, Pike J, Smith TL. Partial sleep deprivation reduces natural killer cell activity in humans. Psychosom Med.1994;56:493-8. 